\title{
Recent Trends and Future Predictions until 2060 of Urban Warming in Four Israeli Cities Employing the RegCM Climate Model
}

\author{
Hofit Itzhak-Ben-Shalom¹, Rana Samuels²*, Oded Potchter ${ }^{3,4}$, Pinhas Alpert ${ }^{2}$ \\ ${ }^{1}$ The Porter School of Environmental Studies, Tel-Aviv University, Tel-Aviv, Israel \\ ${ }^{2}$ Department of Geosciences, Tel-Aviv University, Tel-Aviv, Israel \\ ${ }^{3}$ Department of Geography and the Human Environment, Tel-Aviv University, Tel-Aviv, Israel \\ ${ }^{4}$ Department of Geography, Beit-Berl Academic College, Tel-Aviv, Israel \\ Email: hofitben@gmail.com, pinhas@post.tau.ac.il, potchter@post.tau.ac.il
}

How to cite this paper: Itzhak-Ben-Shalom, H., Samuels, R., Potchter, O. and Alpert, P. (2016) Recent Trends and Future Predictions until 2060 of Urban Warming in Four Israeli Cities Employing the RegCM Climate Model. American Journal of Climate Change, 5, 464-484.

http://dx.doi.org/10.4236/ajcc.2016.54034

Received: June 26, 2016

Accepted: October 31, 2016

Published: November 3, 2016

Copyright $\odot 2016$ by authors and Scientific Research Publishing Inc. This work is licensed under the Creative Commons Attribution International License (CC BY 4.0).

http://creativecommons.org/licenses/by/4.0/

(c) (i) Open Access

\begin{abstract}
During periods of global warming (GW), expected increases in urban temperatures can have adverse impacts on city climate and thermal discomfort due to combined urban and global warming effects. The different climates in four cities in Israel are studied for the purpose of differentiating global vs. urban warming. Trends in urban and nearby rural areas were compared in order to estimate the urbanization effect on the local climate zones. Daily 06:00 and 15:00 Local Time (LT) temperatures for July 1980-2014 were investigated. The linear relationship between the urban warming and population growth observed in present climate data is assumed to continue into the near future. The Regional Climate Model (RegCM) temperature trends into the 21st century are assumed to represent primarily the GW because of the relatively coarse grid interval of $25 \mathrm{~km}$. Hence, this study first differentiates between global and local warming past trends, and then uses this past result to make future projections that consider both factors. A unique feature of this study is the large climatic variety over Israel-a small country that encompasses no less than 5 different Köppen climatic zones. The urban minus rural temperature (1980-2014) changes, $\Delta \mathrm{T}_{\mathrm{u}-\mathrm{r}}$, show more intense warming in the afternoon in all 4 cities. For instance, in Jerusalem and Eilat, the $\Delta \mathrm{T}_{\mathrm{u}-\mathrm{r}}$ has increased by $\sim 1.2^{\circ} \mathrm{C}$. Following the RegCM predictions, by 2060 with "No population growth", this temperature increase is expected to continue, by $1.114^{\circ} \mathrm{C}$ and $1.119^{\circ} \mathrm{C}$, respectively. If, however, these cities grow rapidly, air temperature will increase by $2.937^{\circ} \mathrm{C}-4.129^{\circ} \mathrm{C}$ and $2.778^{\circ} \mathrm{C}-3.939^{\circ} \mathrm{C}$, respectively.
\end{abstract}

\section{Keywords}

Urban Warming, Climatic Change, Future Prediction, Global Warming, Israeli Cities

${ }^{*}$ Deceased, 23rd October 2014. 


\section{Introduction}

Cities, towns and settlements contain more than $50 \%$ of the Earth's population [1]. From an environmental standpoint, cities are viewed as an efficient way to concentrate intensive human impacts on the one hand; while on the other, they embody a plethora of negative environmental impacts that cross scale and municipal boundaries [2]. Furthermore, human activity and resource consumption can create warmer local conditions in cities as compared with surrounding areas. Given the fact that urban areas and their populations will continue to grow in size and number, it is expected that urbanized growth will have global consequences [3].

The main reasons for intensified heating in cities, otherwise known as Urban Heat Islands (UHI), are differences in solar heat storage, anthropogenic heat release and evaporation differences between urban and rural areas [4]. In rural areas, plants take moisture from deeper ground, which enhances evaporation [5]. Due to the differences in evaporation, the larger proportion of the heat in urban areas is in sensible form [6]. Given the main urbanization characteristics such as land use change, street geometry and albedo effects, the urban climate (as compared to rural area nearby) is often characterized by amplified air temperature, lower humidity and moderated wind velocities [5] [7].

Cities are also emerging as an important source of uncertainty in regional-to-global scale biogeophysical processes [8]. Urban land use can influence local as well as regional climates through the UHIs [9] [10].

Hence, urban populations are exposed to both urban climate modifications on a local scale, and to the effect of regional and global climate changes on a larger scale. This combination of local and global warming tends to be exacerbated during summer months [11]. For example, in the US, it is estimated that changes in land cover over agricultural and urban areas are inducing surface warming of $0.27^{\circ} \mathrm{C}$ per century [12]. In China, the average temperature increase was $\sim 0.05^{\circ} \mathrm{C} / \mathrm{dec}$; in Southeastern China the warming has been attributed to urban sprawl [13].

Recent studies, based on the rate of observed urban warming, predict that the combined impact of global warming (GW) and urban warming on human thermal sensation will significantly increase in the coming years [14]. Of these, only a few climate model studies have focused on subtropical climates, and even fewer have dealt with arid climates [15] [16] [17]. Furthermore, considerable uncertainty exists regarding the magnitude of warming according to any given scenario due to the effect of changes in atmospheric composition and changing regional land uses. Most climate models have used recent observations. Because they incorporate large-scale patterns of past climate change but not the magnitude of change by region, efforts to reduce model-related uncertainty of climate prediction, based on the parameter limitations, have been initiated [18]. We should note that the complex physical processes often make it impossible to trace these effects in GCMs [16]. In addition, the available climate models generally have insufficient spatial resolution when applied to small countries like Israel. Because our method compensates for some of these limitations, the air temperature changes 
described in the current study can be employed as a tool to emulate and better understand the climate change in the selected Israeli and, by implication, other cities.

The observed linearity exhibited by our results was found to be strong (see Figure 2 and Figure 3), implying that non-linear transformations would not produce representative results (personal communication with statistician). Hence, it was assumed that the correlation between population and local warming is linear for the three population scenarios we simulated. This outcome provides a gross assessment for different levels of urban development, including strength of urban design, local climate, population growth and other selected variables. Current (1980-2014) local increases in the temperature change rates could thus be estimated with the urban and rural data at the four different sites selected. The main goals of the present study were:

- To examine the change in air temperatures in four Israeli cities located in different climatic zones as compared to nearby rural stations.

- To predict the urban warming based on proxies for urbanization, such as population growth and regional climate model predictions.

Israel's climate is unique due to the variety of its climatic regions (five different Köppen zones), spread over a relatively small area (Figure 1): coastal Mediterranean climate, mountain Mediterranean climate, semi-arid climate, arid climate and hyperarid climate. Previous studies have quantified the warming due to those local climatic changes associated with GW [19] [20] [21]. The authors of these studies [22] analyzed the minimum and the maximum summer air temperature from 40 stations (during 1964-1994) and found minimum and maximum air temperature decadal increases of $0.26^{\circ} \mathrm{C}$ and $0.21^{\circ} \mathrm{C}$. Others [23] analyzed air temperature data from 16 stations in Israel between the years 1975 and 2008 and found that the average air temperature significantly increased by $0.4^{\circ} \mathrm{C}-1.1^{\circ} \mathrm{C}$ per decade. Recent studies using climate models suggest average temperature increases by $1.5^{\circ} \mathrm{C}-2.5^{\circ} \mathrm{C}$ by 2060 [24], and that the rise in extreme temperatures and heat waves will be even more intense [21]. One focal issue arising here with respect to urban warming is the quantification of GW versus urban warming as distinct trends.

\section{Materials and Methods}

\subsection{Data Sets}

Observed data: Observed data were obtained from the Israel Meteorological Service (IMS) for stations in both urban and rural areas, for July 1980-2014. These measurements are available 4 - 8 times a day, depending on the station. For reasons of comparability, the focus here was on the morning (06:00) and the afternoon (15:00) air temperatures at local time (LT).

The Regional Climate Model (RegCM): Future climate data are based on results from the model simulation run in Tel-Aviv University. This model applied was the RegCM3, developed by the Abdus Salam International Centre for Theoretical Physics (ICTP), as determined from the lateral boundaries by the results of ECHAM5-Max Planck Institute Ocean Model 1 [25]. The model simulated the period 1961-2060 under Special 
$35^{\circ}$

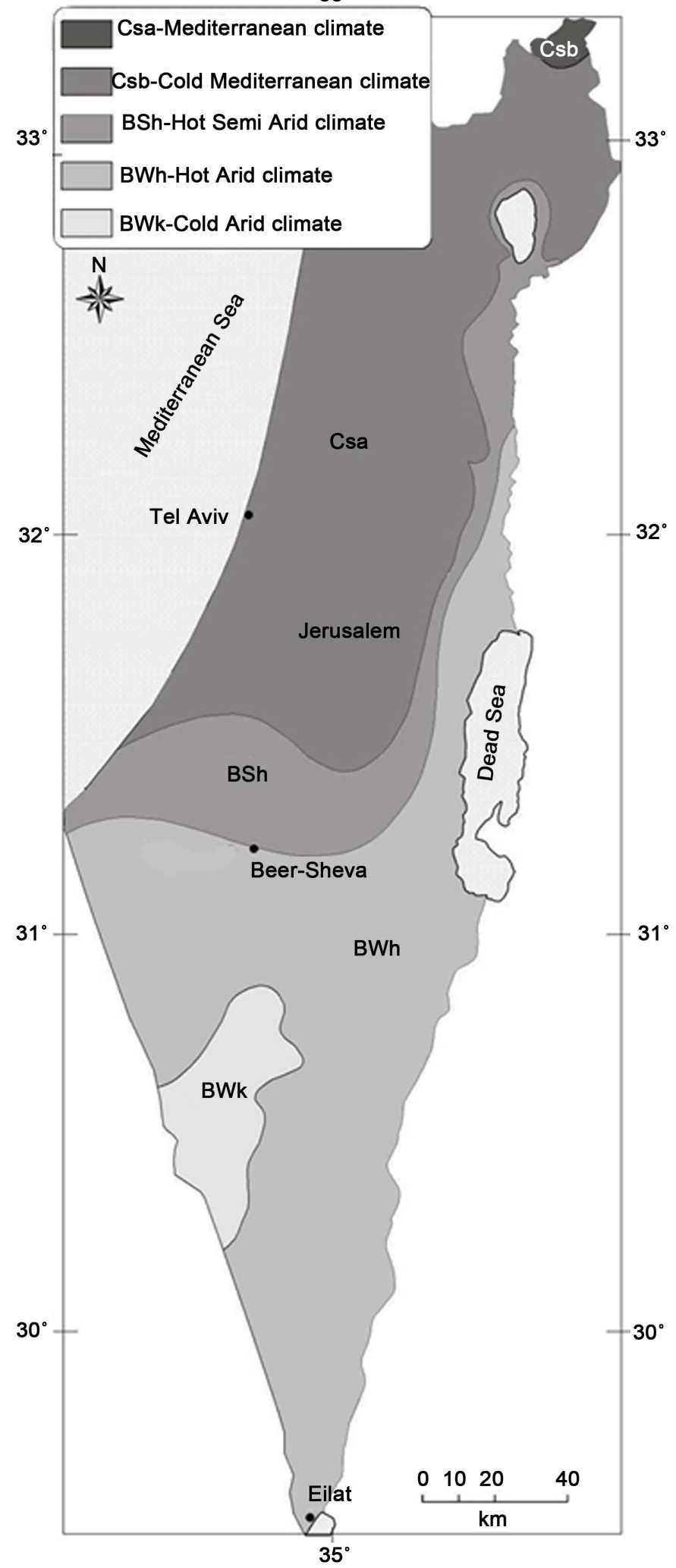

Figure 1. Map of Köppen climatic classification of Israel and the four chosen cities in this study, i.e. Tel-Aviv, Jerusalem, Beer-Sheva and Eilat. 
Report on Emissions Scenarios (SRES) A1B, where a balance between fossil fuel and energy sources was used (further details about the simulation can be found in [21] [24]. Here, the model was run with a grid interval of $25 \mathrm{~km}$.

Population data: Population data for the years 1980-2014 was provided by the Israeli Central Bureau of Statistics (CBS) [26] and from the Population, Immigration and Border Authority (PIBA) [27]. During the 35 years in question (i.e., 1980-2014), the number of inhabitants in Jerusalem increased to $205.2 \%(+417.909 \mathrm{p} / 35 \mathrm{y})$, in BeerSheva to $198 \%(+101.788 \mathrm{p} / 35 \mathrm{y})$ and in Eilat to $278 \%(+30.840 \mathrm{p} / 35 \mathrm{y})$ (Table 1).

According to PIBA and Human Rights Watch [27] [28] the number of illegal immigrants in Israel includes more than 55,000 people, who are concentrated in two centers; Tel-Aviv (60\% or 6600 people) and Eilat (more than $20 \%$ or 11,000 people) [29]. Note, that the population in Tel-Aviv was just 404,400 inhabitants in 2014. However, we used the Tel-Aviv district population data, indicating a population of 1.331 million in TelAviv proper and its 11 neighboring cities, known as "Gush Dan" (the area of Greater Tel-Aviv) [26]. In order to evaluate the anthropogenic contribution to climate change, population growth was used as a proxy, as often found in UHI measures [5] [30]. However, contemporary research suggests that population is not a reliable proxy for urbanization [31] [32] [33] with other measures, such as: urban structure, urban cover, urban fabric, and urban metabolism, perhaps more relevant [33] [34]. The reasons, for employing the population data proxy here were as follows. First, population growth data is readily available [35] and has already been widely used as the common indicator by urban climatologists [5] [11] [23] [30] [36]. In addition, we find similarities in the characteristics (construction methods, materials and colors) of the built-up areas in Israel's urban locations, particularly in the four chosen cities. Second, similarities in building types, mainly compact mid-rise and high-rise, enabled us to compare Land Cover Types in the different climate zones of the four cities. The third reason for doing so was that the Israeli authorities publish future predictions for population growth (e.g., until 2059). According to these forecasts, Israel's population is expected to grow by a factor of 1.7 [37]. Use of population variable as a proxy thus allowed us to include the urban impact on future climate.

Table 1. Study area and population growth information for the four chosen cities.

\begin{tabular}{|c|c|c|c|c|c|c|}
\hline $\begin{array}{l}\text { Name of } \\
\text { the city }\end{array}$ & Location & $\begin{array}{c}\text { Population } \\
\text { (1000's) } \\
\text { n } 1980 \\
\end{array}$ & $\begin{array}{l}\text { Population } \\
\text { (1000's) } \\
\text { in } 2014 \\
\end{array}$ & $\begin{array}{l}\text { Population } \\
\text { growth \% }\end{array}$ & $\begin{array}{c}\text { Köppen } \\
\text { climatic } \\
\text { classification }\end{array}$ & $\begin{array}{c}\text { Location } \\
\text { Description }\end{array}$ \\
\hline $\begin{array}{l}\text { Greater } \\
\text { Tel-Aviv }\end{array}$ & $\begin{array}{l}32^{\circ} 06^{\prime} \mathrm{N} \\
34^{\circ} 47^{\prime} \mathrm{E}\end{array}$ & 969.2 & 1331.3 & $+37.4 \%$ & $\begin{array}{c}\text { Csa: } \\
\text { Mediterranean } \\
\text { climate }\end{array}$ & $\begin{array}{c}\text { Central Israel; } \\
\text { Mediterranean } \\
\text { coast }\end{array}$ \\
\hline Jerusalem & $\begin{array}{l}31^{\circ} 46^{\prime} \mathrm{N} \\
35^{\circ} 13^{\prime} \mathrm{E}\end{array}$ & 397.391 & 815.300 & $+105.2 \%$ & $\begin{array}{c}\text { Csa: } \\
\text { Mediterranean } \\
\text { climate }\end{array}$ & $\begin{array}{l}\text { Judean } \\
\text { Mountains }\end{array}$ \\
\hline Beer-Sheva & $\begin{array}{l}31^{\circ} 15^{\prime} \mathrm{N} \\
34^{\circ} 48^{\prime} \mathrm{E}\end{array}$ & 103.8 & 205.588 & $+98 \%$ & $\begin{array}{c}\text { BSh/ BWh: } \\
\text { Hot semi-arid/arid } \\
\text { climate }\end{array}$ & $\begin{array}{c}\text { Northern edge } \\
\text { of the } \\
\text { Negev desert }\end{array}$ \\
\hline Eilat & $\begin{array}{l}29^{\circ} 55^{\prime} \mathrm{N} \\
34^{\circ} 95^{\prime} \mathrm{E}\end{array}$ & 17.3 & 48.140 & $+178 \%$ & $\begin{array}{c}\text { BWh: } \\
\text { Hot arid climate }\end{array}$ & $\begin{array}{l}\text { Northern tip } \\
\text { of the Red Sea }\end{array}$ \\
\hline
\end{tabular}




\subsection{Study Area}

The case studies were chosen to represent four of the different climatic regions found in Israel (see Figure 1 for the climatic zones and the cities' locations). Since 1950s, the locations of the four respective urban stations have not changed; however, massive urban growth developed around these stations, especially in the cities of Jerusalem and BeerSheva, both of which were characterized by vast open areas enabling expansion. They thus differed from the Tel-Aviv area, which was limited in space and therefore became characterized by high-rise construction. For each city, a nearby rural station was chosen as a reference point so long as it had the same Köppen climatic classification (Table 2). Some technical problems with the stations' data, their respective availability throughout the period studied, the specific hours of operation as well as their data quality and locations are described in detail in the Appendix.

Local climate zones (LCZ) as defined by Stewart and Oke: [32] [33] examined the urban climate and UHIs worldwide through standardized description sites, characterized by uniform surface cover, buildings, materials and human activity. For example, according to Stewart and Oke, the built areas in the four cities are of types 1 and 2 or their subtypes, (Tel-Aviv type B1, 2; Jerusalem type A 1, 2; Beer-Sheva F 2 and Eilat type F 5,2 ), characterized by a dense mix of tall and midrise buildings to tens of stories; the construction materials: concrete, stone, and glass. The streets are covered with few or no trees, and tend to be paved, i.e., the Land Cover Type (LCT) is different in each city (see Table 2(b)).

\subsection{Methodology}

For each set of locations (Table 1; Figure 1), we examined the observed data in order to determine the differences in the rates of change in air temperature. More specifically, we compared the rates of change between the urban and rural data points in each location. It should be noted that the current study focuses on trends rather than on averages. Since climate models incorporate large-scale anthropogenic changes in the form of greenhouse gas scenarios, but not local impacts such as built urban environment, our assumption was that the slopes from the model simulations would be more representative of the rural region.

By applying this approach, the regional effect of climate change could be separated from the local urban impact. For each location we compared the rates of change in urban vs. rural station areas by analyzing the observed data and determining the differences in the rates of change. In addition to studying the effects of urban development, the method described here may provide a potential methodology for estimate of future urban temperature trends.

In order to determine the future urban warming of the chosen cities, the calculated urban component was added to the future projections as realized in the regional climate model (RegCM). By adding population growth trends as determined though analysis of the data, the expected increases could be calculated up to 2060 within the framework of the various population growth scenarios. 
Table 2. Study area of the 4 rural stations (a) and 4 nearby urban stations (b) in the 4 climate regions. According to the constructed area and the LCZ classification. Altitude (m) above Mean Sea Level (MSL) is indicated.

(a)

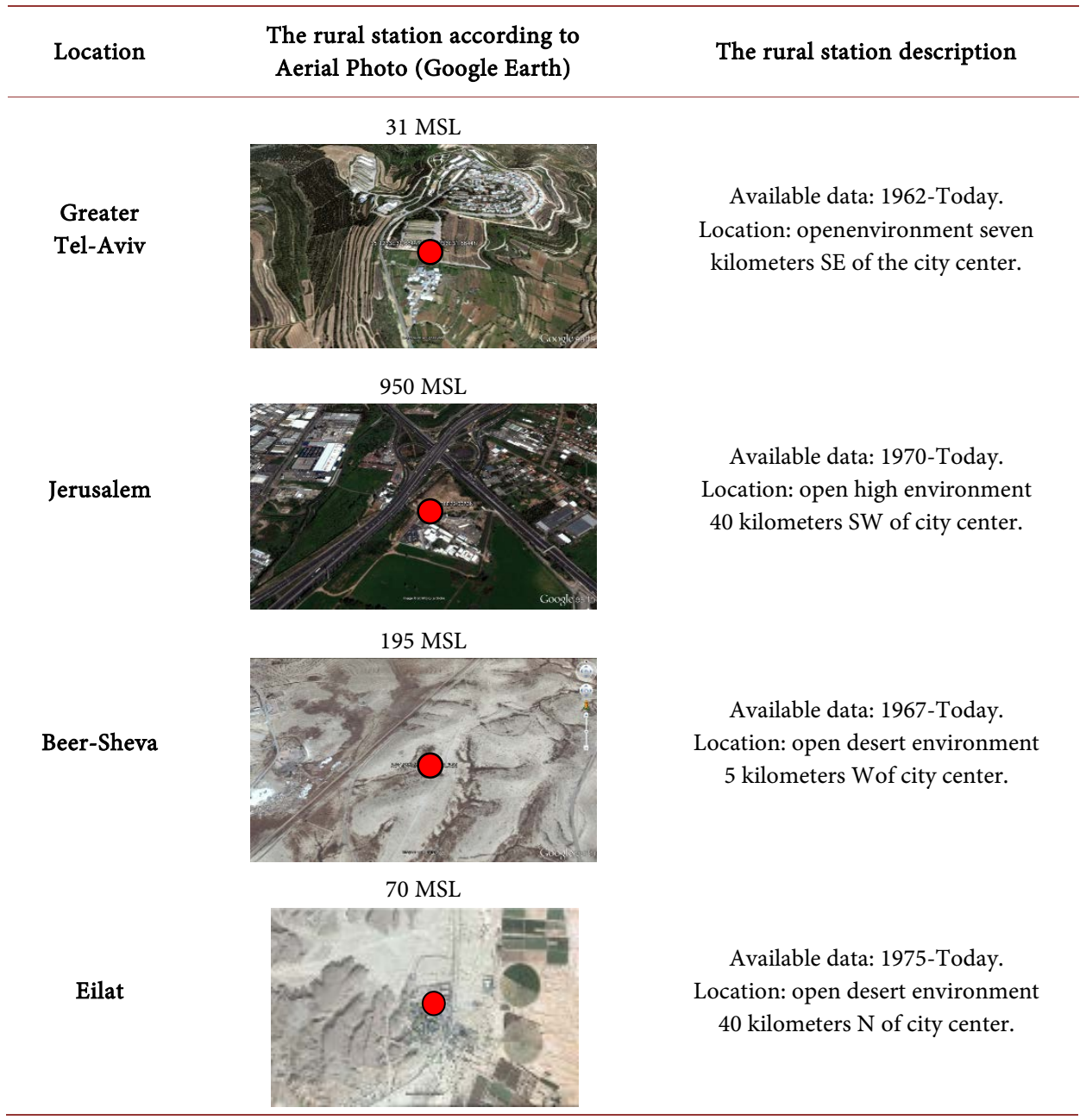

(b)

\begin{tabular}{|c|c|c|c|}
\hline Location & $\begin{array}{c}\text { Location of urban station } \\
\text { (Google Earth) }\end{array}$ & $\begin{array}{c}\text { Constructed } \\
\text { area }(\%)\end{array}$ & LCZ Classification \\
\hline & Urban Total Area $172\left(\mathrm{~km}^{2}\right)$ & $\begin{array}{c}\text { Urban built } \\
\text { area } 56.7\end{array}$ & \multirow{2}{*}{$\begin{array}{c}\text { B1, } 2 \\
\text { Built type: } \\
\text { Dense mix of midrise } \\
\text { and tall building. } \\
\text { Land covers mostly } \\
\text { concrete, glass and } \\
\text { construction materials. } \\
\text { Land cover: scattered } \\
\text { trees: land cover mostly } \\
\text { pervious: lightly wooded } \\
\text { landscape of deciduous } \\
\text { trees. Zone function is } \\
\text { natural tree cultivation, } \\
\text { or urban park. }\end{array}$} \\
\hline $\begin{array}{l}\text { Greater Tel-Aviv } \\
\text { For locations } \\
\text { of all } \\
\text { stations-see } \\
\text { Figure } 4 .\end{array}$ & 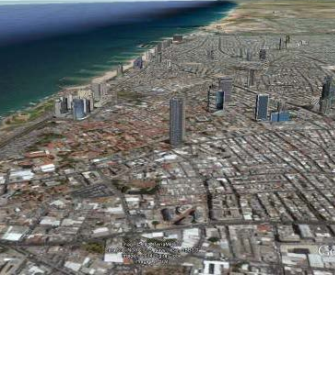 & $\begin{array}{c}\text { area } 56.7 \\
\text { Urban open } \\
\text { area } 5.9 \\
\text { Urban } \\
\text { forests } 3.7\end{array}$ & \\
\hline
\end{tabular}




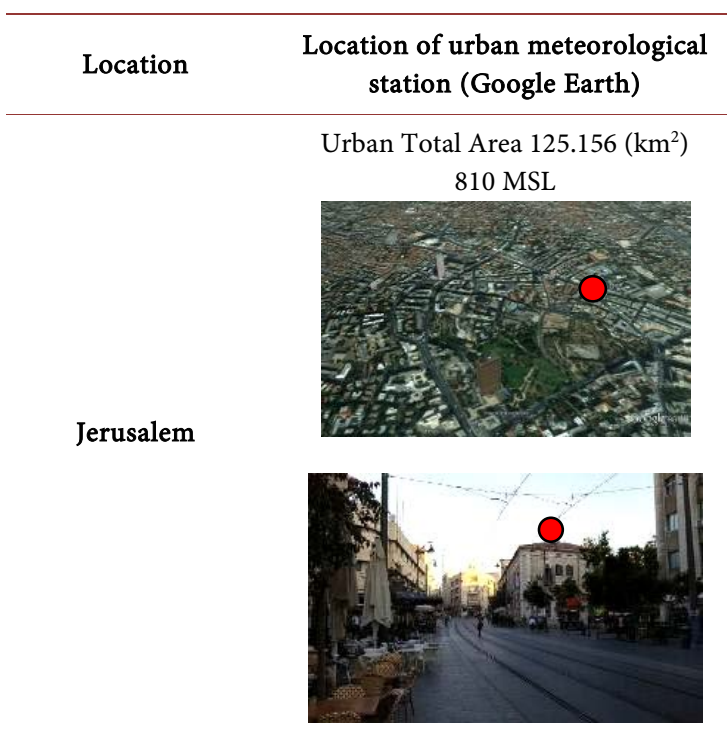

\section{Constructed area (\%)}

LCZ Classification

Urban

built area 34.3

Urban open area 3.3

Urbanforests 20.1

Urban Total Area $59.903\left(\mathrm{~km}^{2}\right)$ 279 MSL

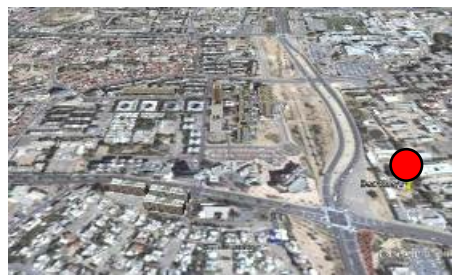

Beer-Sheva

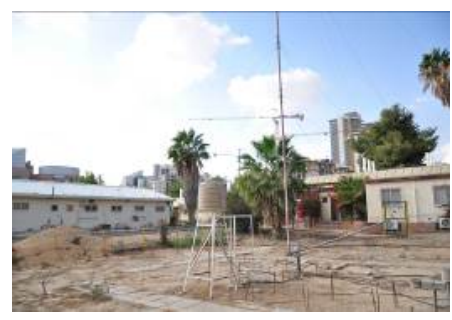

Urban Total Area $84.789\left(\mathrm{~km}^{2}\right) 22$ MSL

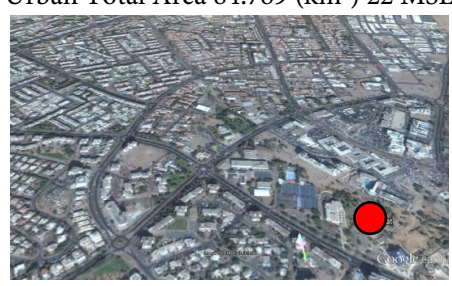

Eilat

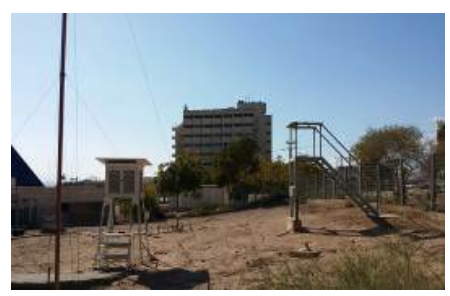

Urban built

area 47.3

Urban open

area 2.3

Urban forests

6.9

Urban built area 11.5

Urban open area 1.1

Urban forests

0.1
$\mathrm{A} 1,2$ Built type: Dense mix of midrise and tall building. Land covers mostly concrete, stone and construction materials. Land cover: dense trees: land cover mostly pervious; heavily wooded landscape of deciduous trees: forest or urban park.

F2

Built type: Mix building of 3 - 9 floor, few tresses. Land covers mostly stone, concrete and construction materials. Land covers type: Bare sand of natural desert.

F 5,2

Built type: open arrangement of midrise building of 3 - 9 floor, few tress. Land covers mostly stone, glass, concrete and construction materials.

Land cover: Bare soil or sand of natural desert. 
Three growth scenarios were chosen:

1) No population growth;

2) Constant population growth;

3) Rapid (constant * 1.7) population growth.

The following linear equation was used to calculate air temperature increases based on projected population growth until the year 2060;

$$
\begin{aligned}
\mathrm{T}\left({ }^{\circ} \mathrm{C}\right) 2060= & \text { POP2060 } *(\Delta \mathrm{TU} \text { obs }-\Delta \mathrm{TRobs}) / \mathrm{POP} 2015 *(46 / 35) \\
& +(\mathrm{TM} 2060-\mathrm{TM} 2015)+\mathrm{T}\left({ }^{\circ} \mathrm{C}\right) 2015
\end{aligned}
$$

where the 2015-2060 temperature change is composed of the first two terms on the right-hand side (RHS) of Equation (1). The first is an anthropogenic factor that is linearly estimated, based on the population growth, while the second term is the GW contribution, based on RegCM model temperatures (TM).

The variables in Equation (1) are defines as follows: POP year-the population for a given year (according to the three growth scenarios); $\Delta$ TUobs-the $35 \mathrm{y}$ observed change in air temperatures in the urban data; and $\Delta$ TRobs-the 35y observed change in air temperatures in the rural data.

Taken together these form the first term of the equation, which represents the local warming effect for the 46y from 2015 to 2060. The second term of Equation (1) provides the global warming model temperature change value, i.e., TM2060-TM2015. It is important to note that the data were recorded according to the original decimal number, a step essential for the next step of the data calculations since any rounding could significantly influence the final $\mathrm{T}$ results. The next Section 3, presents the results, which is followed by the Discussion (Section 4).

\section{Results}

\subsection{The Urbanization Implication}

Here, the correlation between population and local warming is assumed to be linear. The linearity exhibited by our results is clear for in both hours as shown in Figure 2 and Figure 3. The relation between urban air temperature and population growth is illustrated by the scatter plots for the chosen periods in the four cities as found in Figure 2. According to Figure 2, Tel-Aviv shows some small warming at 06:00 LT and a cooling at 15:00 LT, as compared to the other three cities. The highest correlation values were found at 06:00 LT, in the semi-arid city of Eilat $\left(R^{2}=0.626\right)$ and in the arid city of Beer-Shava (0.6896). According to Figure 3, both urban and rural observed air temperature changes showed strong linearity in both hours and for all four cities (see also Table 3). The statistically significant results found in Table 3 show the air temperature change $\left({ }^{\circ} \mathrm{C} / \mathrm{y}\right)$, for 06:00 LT and 15:00 LT in addition to the decadal change $\left({ }^{\circ} \mathrm{C} /\right.$ decade $)$ and the normalized change for populations of $100,000 \mathrm{p}$.

Equation (2) normalizes the "urban minus rural" (i.e., u-r) T change for 100,000 p, based on the estimated linear trend in population; 


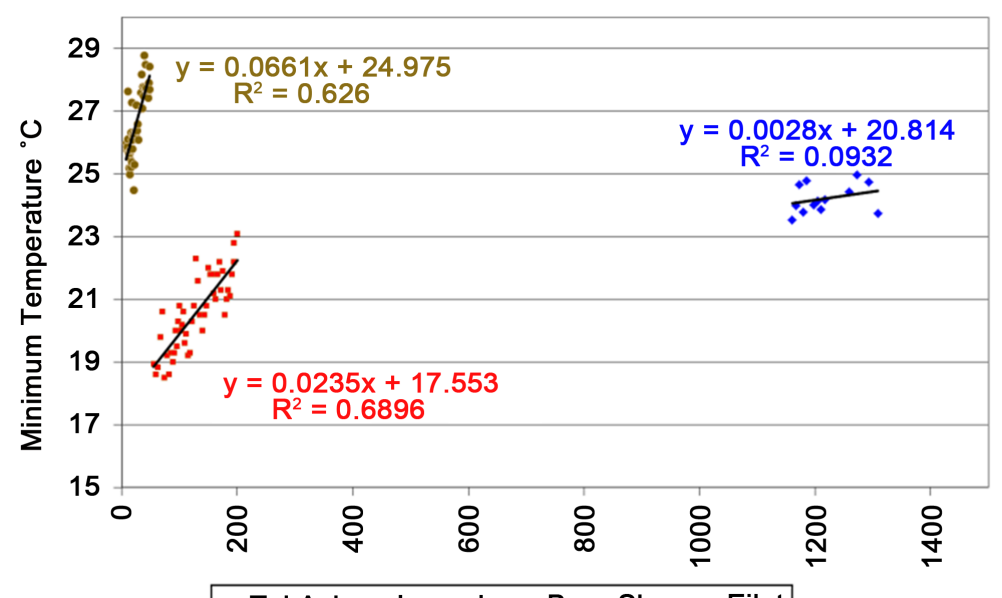

- Tel Aviv $\star$ Jerusalem $₫$ Beer Sheva $\bullet$ Eilat

(a)

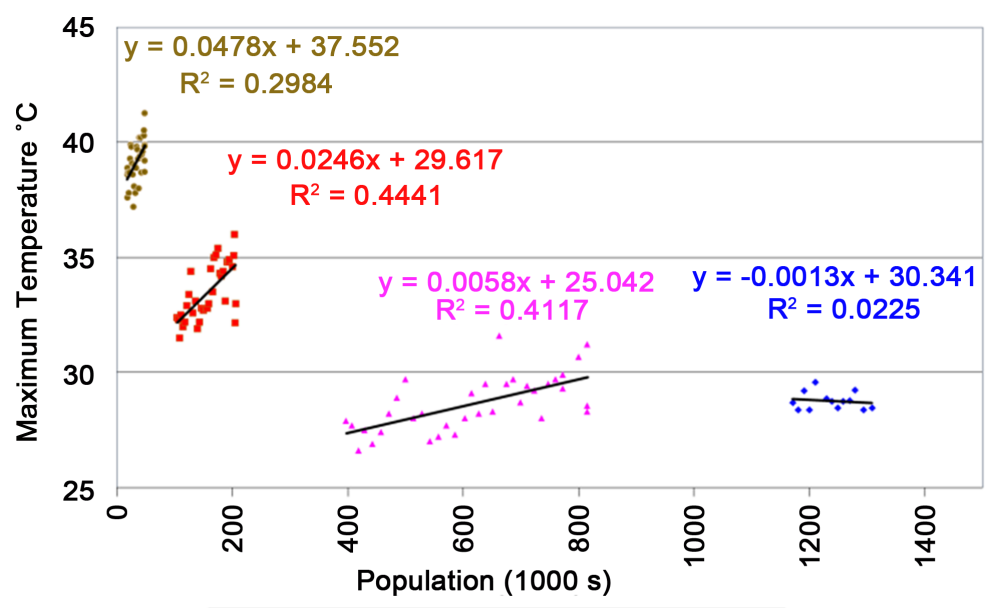

$\bullet$ Tel Aviv $\star$ Jerusalem $\approx$ Beer Sheva $\bullet$ Eilat

(b)

Figure 2. Scatter plots of annual urban air temperatures at 06:00 (a) and 15:00 LT (b), against the population growth during 1980-2014 (for Tel-Aviv represented by the urban station Holon, the period is $1998-2011)$.

$$
\begin{aligned}
& \text { Tu-r Change } / 100000 \mathrm{p} \\
& =\left(\left(\text { TuObs }\left({ }^{\circ} \mathrm{C} / \mathrm{y}\right)-\operatorname{TrObs}\left({ }^{\circ} \mathrm{C} / \mathrm{y}\right)\right) / \text { Pop change }(1000 \mathrm{p} / \mathrm{y})\right) * 100
\end{aligned}
$$

Note that only Eilat, the hyper-arid city in the study area, has a population of less than 50,000, a number that yields an artificially high normalized warming for 100,000 p. Hence, the results for the normalized urban warming for cities with populations below 100,000, at both hours, may be exaggerated. Table 3(a) presents the results for Jerusalem, Beer-Sheva and Eilat during 1980-2014, whereas Table 3(b) presents the results for the five different stations within Greater Tel-Aviv.

According to Table 3(a), the rural and urban slopes from the model are as expected, quite close to the rural observed value for the three cities, but the observed urban temperatures exhibit higher slopes especially at 15:00 LT (for instance, in Jerusalem the 
Table 3. Temperature linear slopes in $\left({ }^{\circ} \mathrm{C} / \mathrm{y}\right)$ during 1980-2014 are indicated for the three cities of Jerusalem, Beer-Sheva and Eilat (a), while in (b) the 5 meteorological stations within Greater Tel-Aviv are shown. Statistically significant slopes at a $95 \%$ (i.e., $P<0.05$ ) are in bold. In parentheses, the $\left(\mathrm{R}^{2} ; P\right.$-value $)$ are also indicated.

(a)

\begin{tabular}{|c|c|c|c|c|c|c|}
\hline & \multicolumn{2}{|c|}{ Jerusalem } & \multicolumn{2}{|c|}{ Beer-Sheva } & \multicolumn{2}{|c|}{ Eilat } \\
\hline & $06: 00$ & $15: 00$ & $06: 00$ & $15: 00$ & $06: 00$ & $15: 00$ \\
\hline T Rural Mod $\left({ }^{\circ} \mathrm{C} / \mathrm{y}\right)$ & NA & 0.0288 & 0.0276 & 0.0276 & 0.0310 & 0.0310 \\
\hline T Urban Mod $\left({ }^{\circ} \mathrm{C} / \mathrm{y}\right)$ & NA & 0.0290 & 0.0299 & 0.0299 & 0.0342 & 0.0342 \\
\hline T Rural Obs $\left({ }^{\circ} \mathrm{C} / \mathrm{y}\right)$ & NA & 0.0371 & 0.0690 & 0.0610 & 0.0764 & 0.0095 \\
\hline T Urban Obs $\left({ }^{\circ} \mathrm{C} / \mathrm{y}\right)$ & NA & $\begin{array}{c}0.0742 \\
(0.4 ; 0.001)\end{array}$ & $\begin{array}{c}0.0699 \\
(0.52 ; 0.001)\end{array}$ & $\begin{array}{c}0.0760 \\
(0.41 ; 0.001)\end{array}$ & $\begin{array}{c}0.0944 \\
(0.72 ; \mathbf{0 . 0 0 1})\end{array}$ & $\begin{array}{c}0.0460 \\
(0.30 ; 0.001)\end{array}$ \\
\hline$\Delta \mathrm{T}_{\mathrm{u}-\mathrm{r}}\left({ }^{\circ} \mathrm{C} / \mathrm{dec}\right)$ & NA & 0.3709 & 0.0090 & 0.1497 & 0.1802 & 0.3657 \\
\hline $\begin{array}{c}\text { Pop change } \\
\text { (in } 1000 \mathrm{p} / \mathrm{y} \text { units) }\end{array}$ & \multicolumn{2}{|c|}{12.9060} & \multicolumn{2}{|c|}{3.1717} & \multicolumn{2}{|c|}{1.0295} \\
\hline $\begin{array}{c}\Delta \mathrm{T}_{\mathrm{u}-\mathrm{r}} \text { normalized } \\
\left({ }^{\circ} \mathrm{C} / 100,000 \mathrm{p}\right)\end{array}$ & NA & 0.2874 & 0.0285 & 0.4720 & 1.7506 & 3.5517 \\
\hline
\end{tabular}

(b)

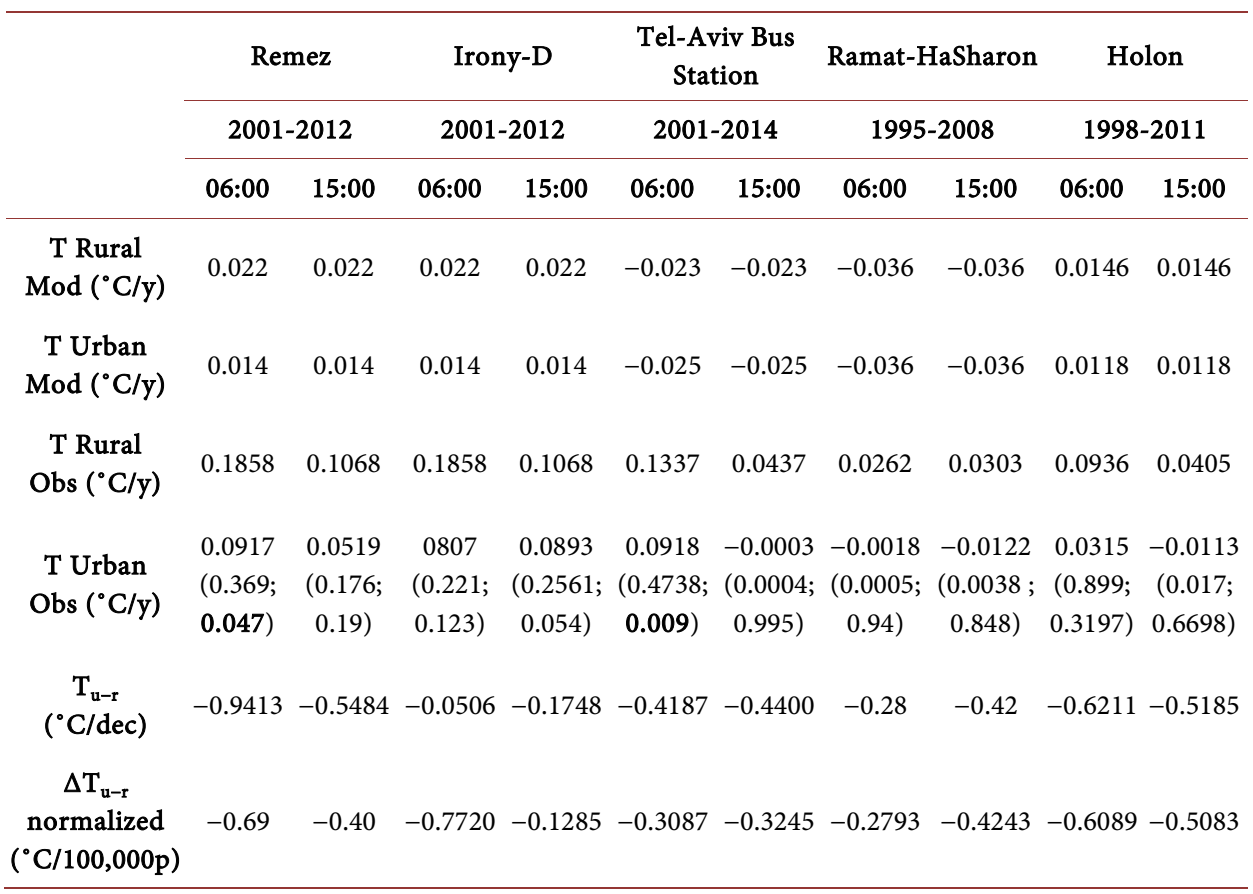

observed urban slope is $0.0742^{\circ} \mathrm{C} / \mathrm{y}$ compared to $0.0371^{\circ} \mathrm{C} / \mathrm{y}$ for the observed rural while in the model the corresponding slopes are 0.0290 and $0.0288^{\circ} \mathrm{C} / \mathrm{y}$ ). In addition, the table shows that at 15:00 LT, all the decadal slopes are significant with high correlation values; i.e. $\Delta \mathrm{T}_{\mathrm{u}-\mathrm{r}}\left({ }^{\circ} \mathrm{C} / \mathrm{dec}\right)$ values reach 0.3709 in Jerusalem, 0.1497 in Beer-Sheva, and $0.3657^{\circ} \mathrm{C} / \mathrm{dec}$ in Eilat. 


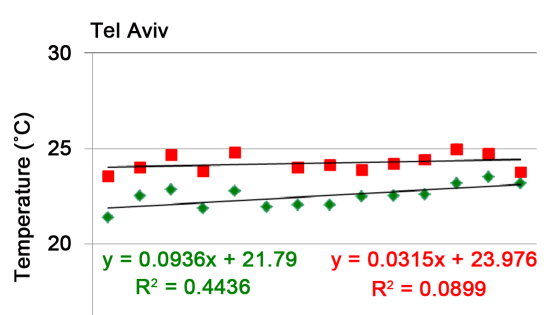

15

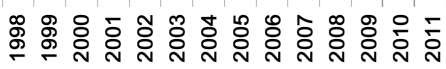
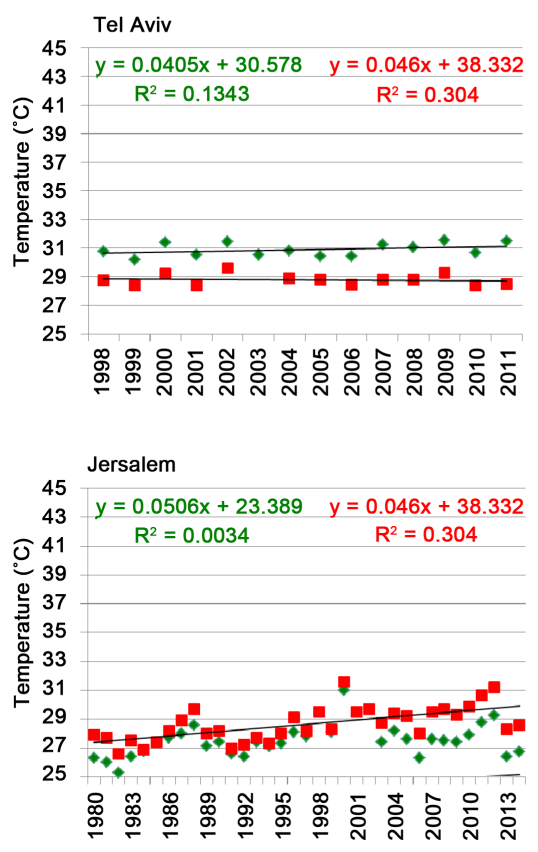

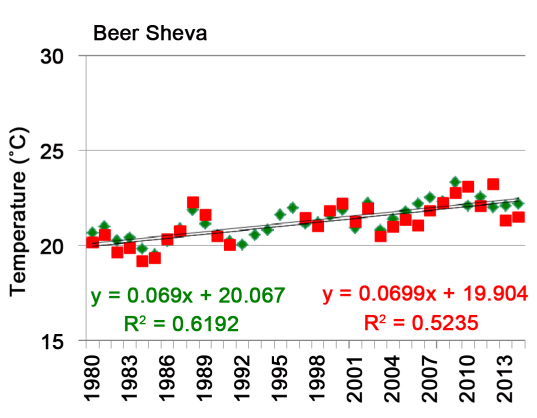

(a)
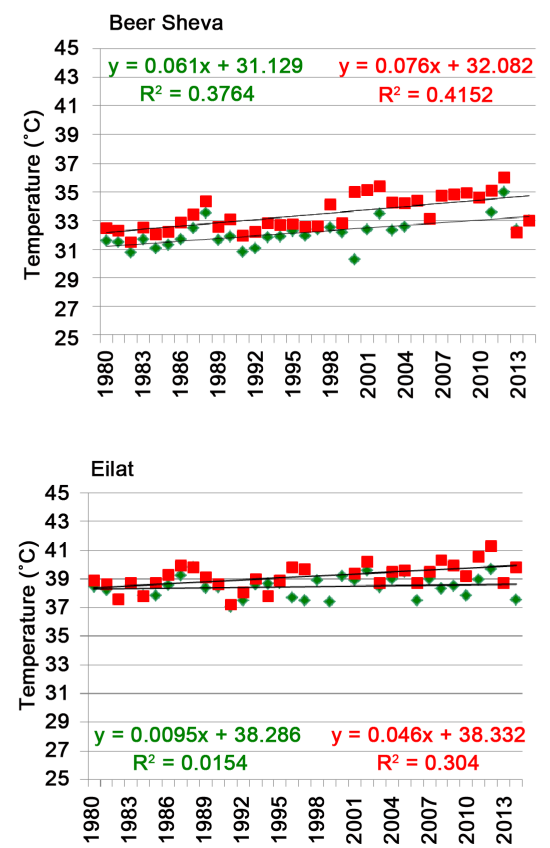

(b)

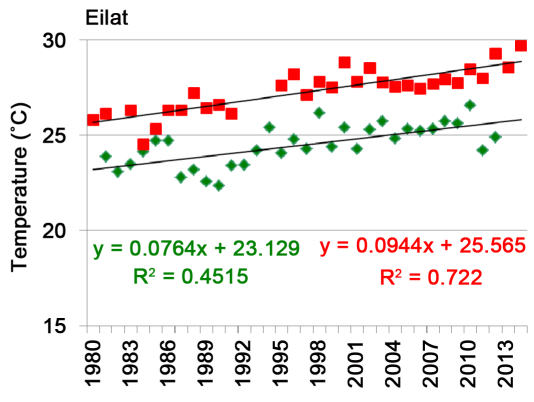

Urban observed

Rural observed

Figure 3. Scatter plots of urban and rural observed air temperatures, at 06:00 (a) and 15:00 LT; (b) during 1980-2014 (1998-2011 for Tel-Aviv).

In Greater Tel-Aviv (Table 3(b)), the slopes from the model simulations are not as close to those of the rural region, probably due to the short periods of time that data were collected while the retrieved data from the 5 urban meteorological stations showed inconsistent results, at both hours. For all stations, the decadal slopes and the normalized urban change for $100,000 \mathrm{p}$ showed decreases over time. Due to the relatively longer period (14y) and its location in the main center city, we focus on the Holon station (see Figure 4 for the geographical locations of the stations). For instance, during 1998-2011, population change Greater Tel-Aviv is 9.472 (in units of 1000 p/y), i.e. the area's population increased by 132,608 .

In Jerusalem, the increase in urban air temperature due to the population growth was $0.0742^{\circ} \mathrm{C} / \mathrm{y}$ and $0.3709^{\circ} \mathrm{C} / \mathrm{dec}$ at $15: 00 \mathrm{LT}$. Hence, the normalized urban change for $100,000 \mathrm{p}$ showed an increase of $0.2874^{\circ} \mathrm{C}$. In Beer-Sheva, the observed urban air temperature showed no significant difference between 06:00 $\left(0.0699^{\circ} \mathrm{C} / \mathrm{y}\right)$ and 15:00 LT 


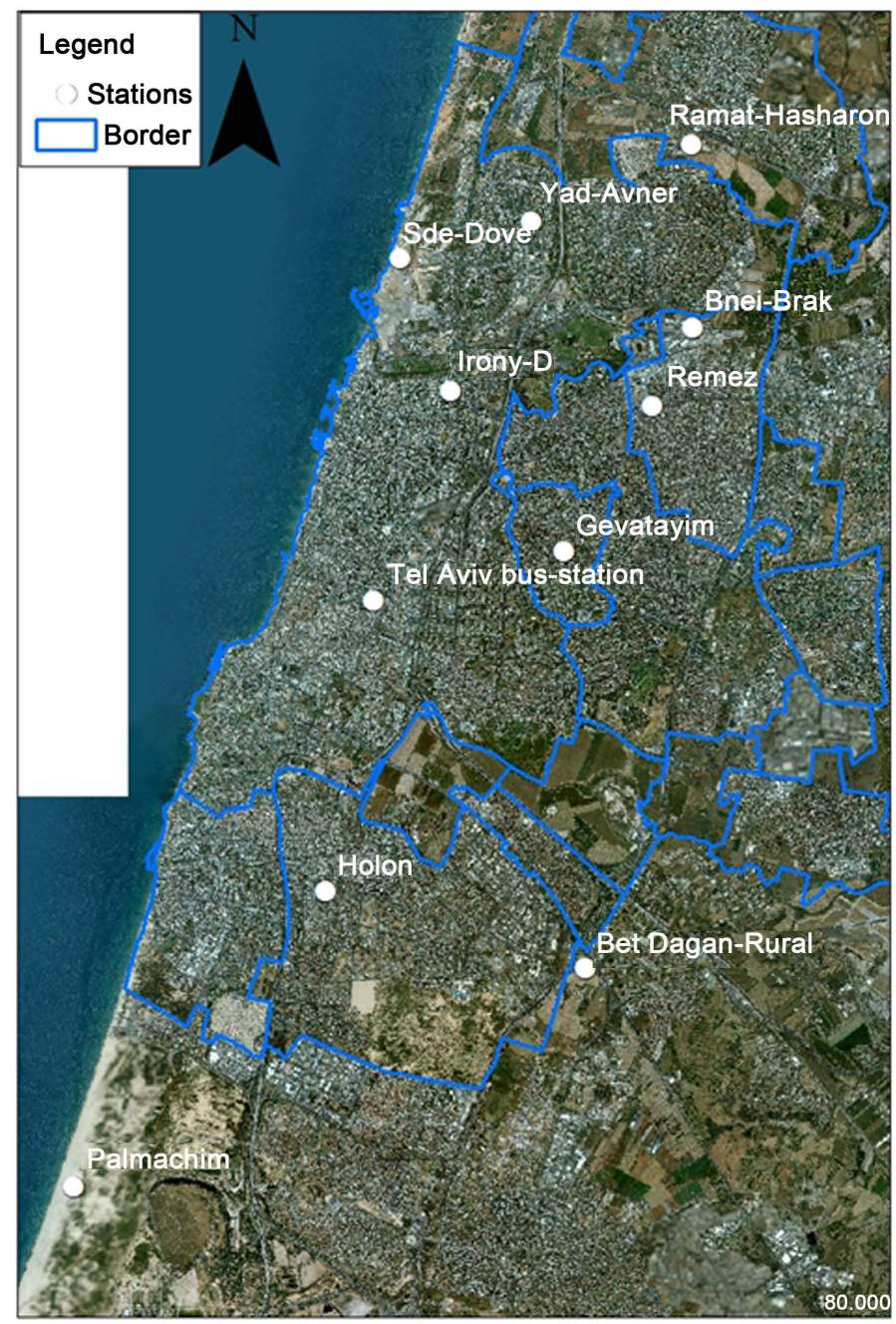

Figure 4. The locations of the relevant meteorological stations in the Greater Tel-Aviv (Gush Dan). The blue line represents the cities' boundaries which together consist of the Greater Tel-Aviv urban area.

$\left(0.0760^{\circ} \mathrm{C} / \mathrm{y}\right)$. However, the $\Delta \mathrm{T}_{\mathrm{u}-\mathrm{r}}$ exhibit a higher slope at 15:00 LT than at 06:00 LT. Hence, the decadal change $\left(0.1497 ; 0.0090^{\circ} \mathrm{C} / \mathrm{dec}\right.$, respectively) and the normalized urban change for $100,000 \mathrm{p}$ showed an increase of 0.4720 and $0.0285^{\circ} \mathrm{C} / 100,000 \mathrm{p}$, respectively. In addition, the highest decadal change was found at 15:00 LT in Jerusalem and Eilat.

\subsection{Past Air Temperature Trends and Future Projections}

We calculated the 06:00 and 15:00 LT observed past and simulated future temperatures until 2060 for various population scenarios for the cities of Jerusalem, Beer-Sheva and Eilat. This was performed by adding the population growth temperature trends to the RegCM model as presented in Figure 5 and Table 4. The y-axis of Figure 5 shows the air temperatures changes relative to the 1980 value over the past decades (left of the black vertical bar) and as projected for 2015-2060 (the right-hand bar); that is, the thick 
Jerusalem (Csa 815,300 pop)

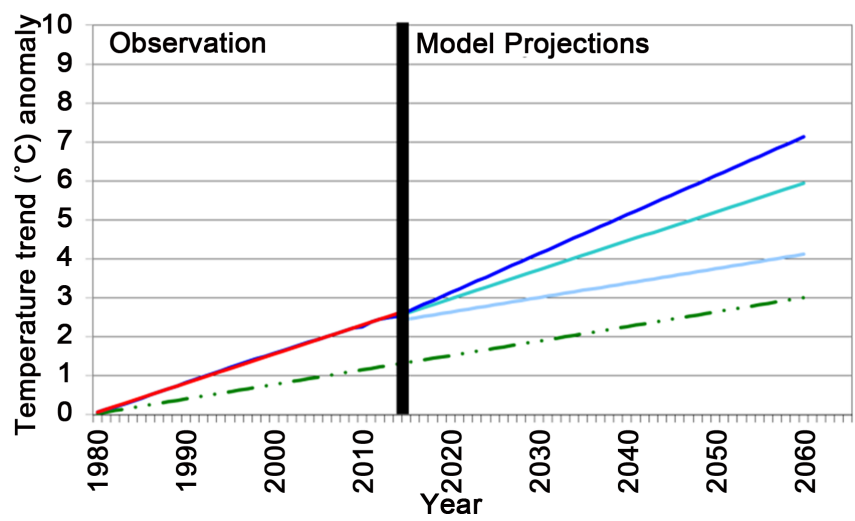

(a)

Beer-Sheva (Bsh 205,588 pop)

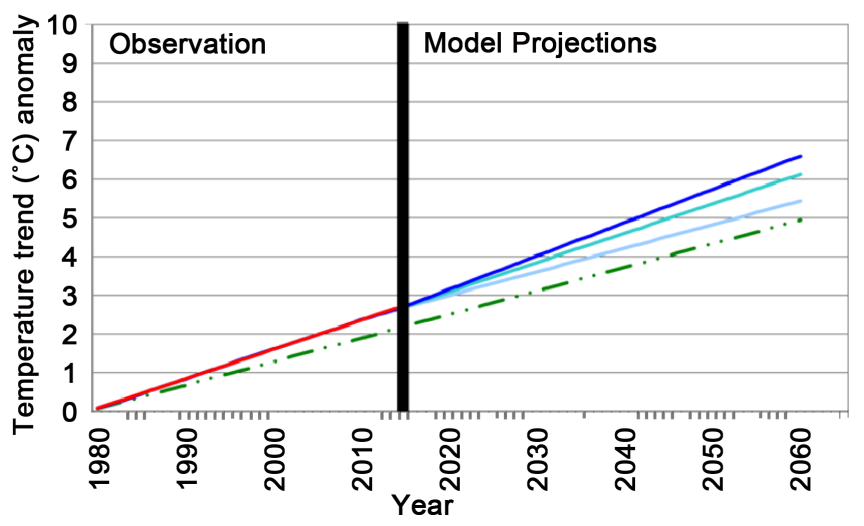

(b)

Eilat (Bwh 48.140 pop)

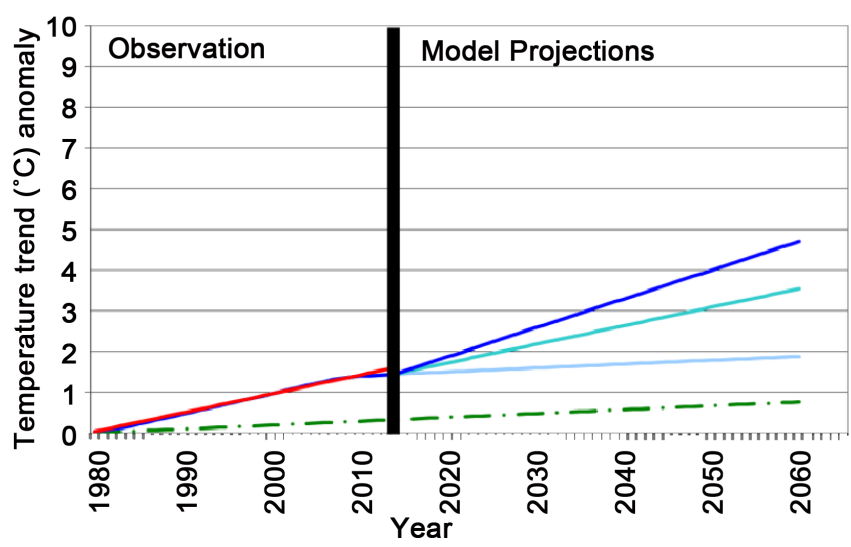

(c)

Figure 5. Air temperature changes at 15:00 LT relative to the year 1980 value: past observations changes (urban and rural, 1980-2014) and future (2015-2060) changes. Three different scenarios for population are considered, no population growth (light blue); constant population (green) and rapid population growth (blue). The vertical black bar at end of 2014 separates the observed period (to the left) from future predictions (to the right). The Köppen geographic climatic classification of Israel is in Figure 1. Populations of the two cities by end of 2014, is indicated. 
Table 4. Observed urban minus rural air temperature changes $\left(\Delta \mathrm{T}_{\mathrm{u}-\mathrm{r}}\right)$ by 2014 (build up since 1980) at 06:00 (a) and 15:00 LT (b) and the $\Delta \mathrm{T}_{\mathrm{u}-\mathrm{r}}$ increases for three future scenarios for 2060. The scenarios are no population growth, constant growth and rapid growth.

\begin{tabular}{|c|c|c|c|c|}
\hline \multirow[b]{2}{*}{ Location } & \multirow{2}{*}{$\begin{array}{c}\mathrm{T}_{\mathrm{u}-\mathrm{r}} \text { changes } \\
\text { until the year } \\
2014\left({ }^{\circ} \mathrm{C}\right)\end{array}$} & \multicolumn{3}{|c|}{ The three different scenarios until the year $2060\left({ }^{\circ} \mathrm{C}\right)$} \\
\hline & & $\begin{array}{c}\text { No } \\
\text { population growth }\end{array}$ & $\begin{array}{c}\text { Constant } \\
\text { population growth }\end{array}$ & $\begin{array}{c}\text { Rapid }\left({ }^{*} 1.7\right) \\
\text { population growth }\end{array}$ \\
\hline \multicolumn{5}{|c|}{ (a) 06:00 LT } \\
\hline Jerusalem & NA & NA & NA & NA \\
\hline Bear Sheva & 0.0315 & 0.030 & 0.071 & 0.100 \\
\hline Eilat & 0.648 & 0.573 & 1.424 & 2.020 \\
\hline \multicolumn{5}{|c|}{ (b) $15: 00 \mathrm{LT}$} \\
\hline Jerusalem & 1.3 & 1.114 & 2.937 & 4.129 \\
\hline Bear Sheva & 0.525 & 0.495 & 1.183 & 1.664 \\
\hline Eilat & 1.2775 & 1.119 & 2.778 & 3.939 \\
\hline
\end{tabular}

vertical bar separates data observed in the past from predictions for the future. The figure in the title of each graph denotes the Köppen climatic classification and population size at the time indicated on the thick vertical line (2014). For instance, in Beer-Sheva, this is indicated by (Bsh, 205,588 pop).

Table 4 shows total air temperature changes in the observed data until the year 2014 and for the three scenarios until 2060. Note that no future prediction is given for Tel-Aviv, due to the limited and problematic database (as discussed in Section 3.1). As shown in Table 4, in Jerusalem, the $\Delta \mathrm{T}_{\mathrm{u}-\mathrm{r}}$ increased by $1.3^{\circ} \mathrm{C}$ at 15:00 LT over the last 35 years. According to the projection, under "No population growth", this temperature increase is expected to continue, by $1.114^{\circ} \mathrm{C}$, until 2060 . If, however, the city grows rapidly, air temperature will increase by $2.937^{\circ} \mathrm{C}$ and $4.129^{\circ} \mathrm{C}$, by 2015 and 2060 , respectively.

In Beer-Sheva, the $\Delta \mathrm{T}_{\mathrm{u}-\mathrm{r}}$ at $06: 00 \mathrm{LT}$ is small $\left(0.0315^{\circ} \mathrm{C}\right)$ when compared to the increase (by $0.525^{\circ} \mathrm{C}$ ) at 15:00 LT over the last 35 years. According to projections, under "No population growth", the trend in temperature increase is expected to continue, by $0.495^{\circ} \mathrm{C}$. If, however, the city should grow rapidly, air temperature will increase by $1.183^{\circ} \mathrm{C}$ and $1.664^{\circ} \mathrm{C}$ at 15:00 LT during 2015-2060.

In Eilat, the $\Delta \mathrm{T}_{\mathrm{u}-\mathrm{r}}$ increased by $0.648^{\circ} \mathrm{C}$ at $06: 00 \mathrm{LT}$ and by $1.2775^{\circ} \mathrm{C}$ at $15: 00 \mathrm{LT}$ over the last 35 years. According to the prediction, under "No population growth", this temperature increase is expected to continue, by 0.573 at $06: 00 \mathrm{LT}$ and by $1.119^{\circ} \mathrm{C}$ at 15:00 LT until 2060. If, however, the city grows rapidly, the air temperature will increase by $1.424^{\circ} \mathrm{C}$ and by $2.02^{\circ} \mathrm{C}$ at $06: 00 \mathrm{LT}$ and $2.778^{\circ} \mathrm{C}$ and $3.939^{\circ} \mathrm{C}$ at $15: 00 \mathrm{LT}$ during 2015-2060. It should be noticed that urban temperature changes $\Delta \mathrm{T}_{\mathrm{u}-\mathrm{r}}$, at both hours during 1980-2014, show the highest increases in the hyper arid zone, that is, Eilat, in comparison to Beer-Sheva. This finding is repeated for the future predictions for the three scenarios even though Eilat is the smallest city in our study. That is, past and fu- 
ture temperature change in Eilat (48,140 people) shows similar trends to those in Jerusalem (815,300 people) at 15:00 LT despite the difference in population size.

\section{Discussion}

This study estimates projected temperature increases caused by urban warming in an era of global warming in four Israeli cities, each having its own unique sub-tropical climatic characteristics. Urban population was used as a gauge for the investigation of urban warming due to the availability of the data, the similarity of building types in the four cities and the Israeli government's long-term practice of predicting future population (details in Section 2.1). Based on a review of numerous cities [30], it was concluded that due to the limited range of urban morphologies, the role of building density and materials, for example, could not be explored in detail. Further study is therefore required to delve into additional parameters, such as city density, energy consumption, and transportation volume, which may also influence urban warming. Some studies did investigate the relationship between UHI intensity and population size; they found that the data indicate some degree of relationship with population, and that $\mathrm{T}_{\mathrm{u}-\mathrm{r}}$ maximum values can be somewhat associated with climatic regions [4] [30] [38].

Urban growth in Israel can be characterized as follows. Since the 1950s, there has been rapid growth in urban population as well as expansion of the built area. By the end of 2013, 43\% of Israel's population (3.4 million) resided in urban areas. This trend is projected to significantly increase in the future [39].

With respect to temperature trends, [40] found that summer UHI intensity in the Greater Tel-Aviv area can reach $2.2^{\circ} \mathrm{C}$ during the day and $0.8^{\circ} \mathrm{C}$ at night. In addition, Israeli government data [27] place the cities of Tel-Aviv and Jerusalem among Israel's three largest and most populated urban centers. Following the LCZ classification [33], one would expect urban temperature change to be more intense in Tel-Aviv as compared with the other three cities selected for study. The current results nonetheless show that urban warming trends in the other three cities, i.e., Jerusalem, Beer-Sheva and Eilat, are higher than in Greater Tel-Aviv.

In Jerusalem, the relatively large increases may be attributed to the Mountain Mediterranean climate (hot dry summer). Regarding Beer-Sheva, the long-term and significant rise in temperature, identified in earlier studies [23] [41], suggest that the temperature changes are associated with considerable and rapid population growth. In the hyper-arid city of Eilat, despite its relatively small population (less than 50,000), our findings show steeply rising trends that fit previous findings [42] indicating development of nighttime and daytime urban heat island intensities. One unique feature of this study is the large climatic variety over Israel-a small country that encompasses no less than five different Köppen zones [43].

\section{Summary and Conclusion}

Future urban air temperatures are expected to increase as a result of land use modifications, changes in the characteristics of urban structures as well as urban sprawl [4] [5]. 
Recent studies applying the RCM [44], together with the Coupled Model Intercomparison Project (CMIP5) [45], have found that by the end of this century, parts of Asia will be uninhabitable.

This is expected to be especially true during the hot season in hot climates and in the Middle East, which is characterized by extreme temperatures [19] [20] [21] [46]. Fujibe [11] has claimed that global and regional warming can aggravate urban warming during summer months, and consequently increase the frequency and duration of air temperature extremes in urban areas, events that are more pronounced in arid regions [47]. The UHI has become the best-documented instance of inadvertent human climate modification [5], with the understanding of urban warming intensity playing an important role in policy decisions [48].

Most UHI studies have focused on cities at mid and high latitudes, which show strong seasonal variation; it was thus assumed that in subtropical cities of similar population size, UHI intensity would be relatively lower [30]. In addition, most climate models incorporate large-scale patterns, making it impossible to accurately simulate sub-grid-scale physical processes [16] [18] that are particularly noticeable in small countries such as Israel. Therefore, the present methodology can be employed as a tool to study and better understand climate change in urban localities such as Israeli cities. The simple methodology suggested involves obtaining a preliminary estimate for the effects of urbanization on air temperature increases over different subtropical climatic zones by means of a regional climate model that incorporates the potential effect of population growth. More specifically, the study reported here attempted, first, to differentiate between global and local warming past trends. It then used this historical information to create a more realistic future projection by taking into consideration both aspects, i.e., the GW and the urban heat effect. While this research provides a "first estimate" of the expected urban changes, it is possible to extend the methodology globally, to cities located in different climatic and geographic regions for the purpose of better understanding the urbanization effect on trends in temperature change.

The current results suggest that given the impact of UHIs on temperature, specifically in cities in hot and dry summer regions, planners and architects should pay special attention to the possible consequences of urban development and population growth on air temperature.

\section{Acknowledgements}

This research was funded through the International Virtual Institute DESERVE (Dead Sea Research Venue), funded by the German Helmholtz Association, the Ministry of Environmental Protection (102-5-1), the Smaller-Winnikow Scholarship Fund in cooperation with the Keren KeyemetL'Israel (Jewish National Fund-JNF), and the Gordon Center for Energy Studies. Additional generous support and cooperation was provided by The Porter School of Environmental Studies.

\section{References}

[1] Department of Economic and Social Affairs, Population Division (2011) World Population 
Prospects, 2010 Revision. United Nations, New York.

[2] Mills, G. (2007) Cities as Agents of Global Change. International Journal of Climatology, 27, 1849-1857. http://dx.doi.org/10.1002/joc.1604

[3] Grimmond, S. (2007) Urbanization and Global Environmental Change: Local Effects of Urban Warming. The Geographical Journal, 173, 83-88.

http://dx.doi.org/10.1111/j.1475-4959.2007.232_3.x

[4] Oke, T.R. (1973) City Size and the Urban Heat Island. Atmospheric Environment (1967), 7, 769-779. http://dx.doi.org/10.1016/0004-6981(73)90140-6

[5] Oke, T.R. (1987) Boundary Layer Climates. 2nd Edition, Methuen, London.

[6] Cleugh, H.A. and Oke, T.R. (1986) Suburban-Rural Energy Balance Comparisons in Summer for Vancouver, BC. Boundary-Layer Meteorology, 36, 351-369. http://dx.doi.org/10.1007/BF00118337

[7] Landsberg, H.E. (1981) The Urban Climate. Academic Press, New York.

[8] Atkinson, R. (2000) Atmospheric Chemistry of VOCs and $\mathrm{NO}_{\mathrm{x}}$. Atmospheric Environment, 34, 2063-2101. http://dx.doi.org/10.1016/S1352-2310(99)00460-4

[9] Oke, T.R. (1982) The Energetic Basis of the Urban Heat Island. Quarterly Journal of the Royal Meteorological Society, 108, 1-24. http://dx.doi.org/10.1002/qj.49710845502

[10] Offerle, B., Grimmond, C.S.B., Fortuniak, K. and Pawlak, W. (2006) Intraurban Differences of Surface Energy Fluxes in a Central European City. Journal of Applied Meteorology and Climatology, 45, 125-136. http://dx.doi.org/10.1175/JAM2319.1

[11] Fujibe, F. (2009) Detection of Urban Warming in Recent Temperature Trends in Japan. International Journal of Climatology, 29, 1811-1822. http://dx.doi.org/10.1002/joc.1822

[12] Kalnay, E. and Cai, M. (2003) Impact of Urbanization and Land-Use Change on Climate. Nature, 423, 528-531. http://dx.doi.org/10.1038/nature01675

[13] Zhou, L., Dickinson, R.E., Tian, Y., Fang, J., Li, Q., Kaufmann, R.K., Tucker, C. J. and Myneni, R.B. (2004) Evidence for a Significant Urbanization Effect on Climate in China. Proceedings of the National Academy of Sciences of the United States of America, 101, 95409544. http://dx.doi.org/10.1073/pnas.0400357101

[14] Cheung, C.S.C. and Hart, M.A. (2014) Climate Change and Thermal Comfort in Hong Kong. International Journal of Biometeorology, 58, 137-148. http://dx.doi.org/10.1007/s00484-012-0608-9

[15] Ayalew, D., Tesfaye, K., Mamo, G., Yitaferu, B. and Bayu, W. (2012) Outlook of Future Climate in Northwestern Ethiopia. Agricultural Sciences, 3, 608-624.

http://dx.doi.org/10.4236/as.2012.34074

[16] Franchito, S.H. and Rao, V.B. (2015) Studies of Climate Change with Statistical-Dynamical Models: A Review. American Journal of Climate Change, 4, 57-68. http://dx.doi.org/10.4236/ajcc.2015.41006

[17] Oleson, K.W., Monaghan, A., Wilhelmi, O., Barlage, M., Brunsell, N., Feddema, J., Hu, J. and Steinhoff, D.F. (2015) Interactions between Urbanization, Heat Stress, and Climate Change. Climatic Change, 129, 525-541. http://dx.doi.org/10.1007/s10584-013-0936-8

[18] Braconnot, P., Harrison, S.P., Kageyama, M., Bartlein, P.J., Masson-Delmotte, V., AbeOuchi, A., Otto-Bliesner, B. and Zhao, Y. (2012) Evaluation of Climate Models Using Palaeoclimatic Data. Nature Climate Change, 2, 417-424.

http://dx.doi.org/10.1038/nclimate1456

[19] Alpert, P. (2004) The Water Crisis in the E. Mediterranean-and Relation to Global Warming. In: Zereini, F. and Jaeschke, W., Eds., Water in the Middle-East and North Afri- 
ca, Springer, New York, 55-61. http://dx.doi.org/10.1007/978-3-662-10866-6_6

[20] Alpert, P., Krichak, S.O., Shafir, H., Haim, D. and Osetinsky, I. (2008) Climatic Trends to Extremes Employing Regional Modeling and Statistical Interpretation over the E. Mediterranean. Global and Planetary Change, 63, 163-170. http://dx.doi.org/10.1016/j.gloplacha.2008.03.003

[21] Samuels, R., Smiatek, G., Krichak, S., Kunstmann, H. and Alpert, P. (2011) Extreme Value Indicators in Highly Resolved Climate Change Simulations for the Jordan River Area. Journal of Geophysical Research: Atmospheres, 116, D24123. http://dx.doi.org/10.1029/2011JD016322

[22] Ben-Gai, T., Bitan, A., Manes, A., Alpert, P. and Rubin, S. (1999) Temporal and Spatial Trends of Temperature Patterns in Israel. Theoretical and Applied Climatology, 64, 163177. http://dx.doi.org/10.1007/s007040050120

[23] Ziv, B. and Saaroni, H. (2011) The Contribution of Moisture to Heat Stress in a Period of Global Warming: The Case of the Mediterranean. Climatic Change, 104, 305-315. http://dx.doi.org/10.1007/s10584-009-9710-3

[24] Krichak, S.O., Breitgand, J.S., Samuels, R. and Alpert, P. (2011) A Double-Resolution Transient RCM Climate Change Simulation Experiment for Near-Coastal Eastern Zone of the Eastern Mediterranean Region. Theoretical and Applied Climatology, 103, 167-195. http://dx.doi.org/10.1007/s00704-010-0279-6

[25] Roeckner, E., Bäuml, G., Bonaventura, L., Brokopf, R., Esch, M., Giorgetta, M., Hagemann, S., Kirchner, I., Kornblueh, L., Manzini, E., Schlese, U. and Schulzweida, U. (2003) The Atmospheric General Circulation Model ECHAM 5. Part I: Model Description. Report 349, Max Planck Institute for Meteorology, Hamburg.

[26] The Israeli Central Bureau of Statistics. http://www.cbs.gov.il/publications14/rep_07/pdf/intro3_h.pdf

[27] PIBA: The Population, Immigration and Border Authority. http://www.piba.gov.il/Pages/default.aspx

[28] Human Rights Watch 2014. http://www.hrw.org/sites/default/files/wr2014_web_0.pdf

[29] The Population, Immigration and Border Authority (2014). http://www.piba.gov.il/PublicationAndTender/ForeignWorkersStat/Documents/sum2014_f inal.pdf

[30] Roth, M. (2007) Review of Urban Climate Research in (Sub)Tropical Regions. International Journal of Climatology, 27, 1859-1873. http://dx.doi.org/10.1002/joc.1591

[31] Karl, T.R., Diaz, H.F. and Kukla, G. (1988) Urbanization: Its Detection and Effect in the United States Climate Record. Journal of Climate, 1, 1099-1123. http://dx.doi.org/10.1175/1520-0442(1988)001<1099:UIDAEI>2.0.CO;2

[32] Runnalls, K.E. and Oke, T.R. (2011) Technique to Detect Microclimatic Inhomogeneities in Historical Records of Screen-Level Air Temperature. Ph.D. Thesis, University of British Columbia, Vancouver.

[33] Stewart, I.D. and Oke, T.R. (2012) Local Climate Zones for Urban Temperature Studies. Bulletin of the American Meteorological Society, 93, 1879-1900. http://dx.doi.org/10.1175/BAMS-D-11-00019.1

[34] Stewart, I.D. and Oke, T.R. (2010) Thermal Differentiation of "Local Climate Zones" Using Temperature Observations from Urban and Rural Field Sites. 9th Symposium on Urban Environment, Keystone, CO, 1-6 August 2010, American Meteorological Society. http://ams.confex.com/ams/19Ag19BLT9Urban/webprogram/Paper173127.html 
[35] Jones, P.D., Kelly, P.M., Goodess, C.M. and Karl, T. (1989) The Effect of Urban Warming on the Northern Hemisphere Temperature Average. Journal of Climate, 2, 285-290. http://dx.doi.org/10.1175/1520-0442(1989)002<0285:TEOUWO >2.0.CO;2

[36] Baker, L.A., Brazel, A.J., Selover, N., Martin, C., McIntyre, N., Steiner, F.R., Nelson, A. and Musacchio, L. (2002) Urbanization and Warming of Phoenix (Arizona, US): Impacts, Feedback and Mitigation. Urban Ecosystems, 6, 183-203.

http://dx.doi.org/10.1023/A:1026101528700

[37] The Israeli Central Bureau of Statistics. http://www.cbs.gov.il/publications/tec27.pdf

[38] Jauregui, E. (1986) Tropical Urban Climates: Review and Assessment. In: Oke, T.R., Ed., Urban Climatology and Its Applications with Special Regard to Tropical Areas, Publication No. 652, World Climate Programme, World Meteorological Organization, Geneva, 26-45.

[39] CBS: The Israeli Central Bureau of Statistics (2014) Characteristics of the Israeli Urban Population. http://www.cbs.gov.il/reader

[40] Bitan, A. and Rubin, S. (1994) Climatic Atlas of Israel. Merav Productions Ltd., Tel Aviv.

[41] Potchter, O. and Itzhak-Ben-Shalom, H. (2013) Urban Warming and Global Warming: Combined Effect on Thermal Discomfort in the Desert City of Beer-Sheva, Israel. Journal of Arid Environments, 98, 113-122. http://dx.doi.org/10.1016/j.jaridenv.2013.08.006

[42] Sofer, M. and Potchter, O. (2006) The Urban Heat Island of a City in an Arid Zone: The Case of Eilat, Israel. Theoretical and Applied Climatology, 85, 81-88. http://dx.doi.org/10.1007/s00704-005-0181-9

[43] Potchter, O. and Saaroni, H. (1998) An Examination of the Map of Climatic Regions of Israel according to the Köppen Classification. Studies IsraePs Geography, 15, 179-194. (In Hebrew)

[44] Pal, J.S. and Eltahir, E.A. (2015) Future Temperature in Southwest Asia Projected to Exceed a Threshold for Human Adaptability. Nature Climate Change, 6, 197-200.

[45] Lelieveld, J., Proestos, Y., Hadjinicolaou, P., Tanarhte, M., Tyrlis, E. and Zittis, G. (2016) Strongly Increasing Heat Extremes in the Middle East and North Africa (MENA) in the 21st Century. Climatic Change, 137, 245-260. http://dx.doi.org/10.1007/s10584-016-1665-6

[46] Shafir, H. and Alpert, P. (2011) Regional and Local Climatic Effects on the Dead-Sea Evaporation. Climatic Change, 105, 455-468. http://dx.doi.org/10.1007/s10584-010-9892-8

[47] Golden, J.S. (2004) The Built-Environment Induced Urban Heat Island Effect in Rapidly Urbanizing Arid Regions-A Sustainable Urban Engineering Complexity. Environmental Sciences, 1, 321-349. http://dx.doi.org/10.1080/15693430412331291698

[48] Chow, W.T., Brennan, D. and Brazel, A.J. (2012) Urban Heat Island Research in Phoenix, Arizona: Theoretical Contributions and Policy Applications. Bulletin of the American Meteorological Society, 93, 517-530. http://dx.doi.org/10.1175/BAMS-D-11-00011.1 


\section{Appendix}

Technical problems in data collection from the IMS or other sources are described in more detail. The main reason for these problems is the study's requirement for long term-meteorological data in different urban and rural areas, which could not be consistently provided. Limitations of the meteorological station data:

Tel-Aviv:

No good urban meteorological station capable of representing the entire urban area could be found in Greater Tel-Aviv (the Tel-Aviv center or surrounding cities). We therefore tried to put together an accurate picture based on data collected from five different urban stations. The three stations located in the Tel-Aviv city center (Remez, Irony-D and the Tel-Aviv central bus station on Petach Tikva Road) were available only from 2001. The two other stations used were located outside the Tel-Aviv center, but within the Greater Tel-Aviv area. The station in Ramat-HaSharon was found to be problematic due to its location outside the city center; whereas the Holon station had operated for only a short period of time (1998-2011). Note that the Holon station was eventually chosen due to its location in the city center (see Figure 4 for the geographical locations of all these stations).

The optimal location for a rural meteorological station was found to be Beit-Dagan, which has been operating since the 1960s in an open area southeast of the Greater Tel-Aviv

Jerusalem:

The meteorological station in Israel's capital, Jerusalem, is located right at the city center. The climate data for 1980-1995 was measured manually; in subsequent years, (1996-2014), the data was collected automatically. Furthermore, until 1996, the manual station in the rural zone was located at 956 meters above MSL; in 1996, the automatic station was transferred to 930 meters above MSL. The changes in altitude could clearly influence the minimum temperature changes measured. In this study, however, only temperatures from the afternoon hour (15:00 LT) are presented because the rural station took measurements only during the day (09:00, 15:00 and 21:00 LT).

Beer-Sheva:

Beer-Sheva's urban station is located inside the city center. The climate data were measured manually until 1995; the data was collected automatically during 1996-2014. The rural meteorological station, located west of Beer-Sheva, is situated in an open desert environment. However, no urban data were available 1992-1996 and no rural data for 2005-2010.

Eilat:

The urban station for Eilat is located in the city center, $1 \mathrm{~km}$ north of the Red Sea coast. No rural meteorological station capable of representing the hyper arid zone was situated nearby; we therefore used the rural station located $40 \mathrm{~km}$ north of Eilat. 
Submit or recommend next manuscript to SCIRP and we will provide best service for you:

Accepting pre-submission inquiries through Email, Facebook, LinkedIn, Twitter, etc. A wide selection of journals (inclusive of 9 subjects, more than 200 journals)

Providing 24-hour high-quality service

User-friendly online submission system

Fair and swift peer-review system

Efficient typesetting and proofreading procedure

Display of the result of downloads and visits, as well as the number of cited articles

Maximum dissemination of your research work

Submit your manuscript at: http://papersubmission.scirp.org/

Or contact ajcc@scirp.org 